\title{
Analysis of multiples in onshore Niger Delta: a prelude to fault shadow phenomenon
}

\author{
G. B. Azuoko ${ }^{1}$ C. N. Ehirim ${ }^{1}$ J. O. Ebeniro ${ }^{1}$ - D. Uraechu ${ }^{2}$
}

Received: 2 September 2016/Accepted: 7 December 2016/Published online: 2 January 2017

(C) The Author(s) 2017. This article is published with open access at Springerlink.com

\begin{abstract}
In this study, multiples have been analyzed as a prelude to fault shadow phenomenon using 3D seismic data from onshore Niger Delta. This involved detailed velocity analysis of a 3D seismic data using semblance plots, from which depth/interval velocity models were generated for two velocity scenarios, the primaries and lower-than-normal velocities in the shadow zone. These velocity models were subsequently used as inputs in prestack depth migration. The result of migration with the lower-thannormal velocities shows that reflections within the shadow zone are coherent, continuous and better aligned than with the primary velocities. This is an indication that these lower-than-normal velocity events have been well accounted for in the shadow zone using these velocities. This result establishes the presence of lower-than-normal velocities in the shadow zone considered as the primary cause of the reflection distortions and misalignment of events observed in the zone, due to multiple reflections. This occurs beyond $3 \mathrm{~s}$ two-way time (3800 m), especially at locations corresponding to the footwall of main boundary faults on seismic. This assertion is made based on the fact that all sources of low-velocity events at this depth such as overpressure and anisotropy have been accounted for by previous researchers in the study area and as such, multiple effects are the only plausible low-velocity
\end{abstract}

C. N. Ehirim

ehirimcn@yahoo.com

1 Geophysics Research Group, Department of Physics, University of Port Harcourt, P.O. Box 122, Choba, Port Harcourt, Nigeria

2 The Shell Petroleum Development Company, Port Harcourt, Nigeria candidate for the observed reflection distortions in the shadow zone.

Keywords Velocities $\cdot$ Multiples $\cdot$ Fault shadow $\cdot 3 D$ seismic data $\cdot$ PSDM

\section{Introduction}

Niger Delta basin is an extensional rift basin located in the Niger Delta. The basin is characterized by structural and stratigraphic complexities dominated by synsedimentary growth faults, rollover anticlines, shale diapirs and steeply dipping closed spaced boundary faults (Haack et al. 2000). The Niger Delta basin is the largest in Africa (Kulke 1995), situated in the Gulf of Guinea (Fig. 1). It is approximately 36,000 square kilometers (about 14,000 sq miles), with substantial hydrocarbon deposits. Hydrocarbon accumulation is domiciled in unconsolidated sands of the tertiary deposits, largely controlled by the growth faults and related structures in the basin.

Analysis of seismic data onshore Niger Delta revealed that beyond $3 \mathrm{~s}$ of two-way travel time(about $3800 \mathrm{~m}$ ), seismic reflection events become discordant and distorted and loose continuity and stratigraphic definition and ultimately placement of wells become impossible. This effect is known as the fault shadow effect, and the zone where this occurs in seismic is known as the fault shadow zone (Fagin 1996; Kanu et al. 2014).

Several authors (Dutta 2002; Aikulola et al. 2010; Oni et al. 2011; Kanu et al. 2014) have investigated the cause of this phenomenon onshore Niger Delta, the reason for this interest being the significant volume of recoverable hydrocarbon prospect beneath the zone, estimated at about 11 billion barrels (Kanu et al. 2014). Aikulola et al. (2010) 


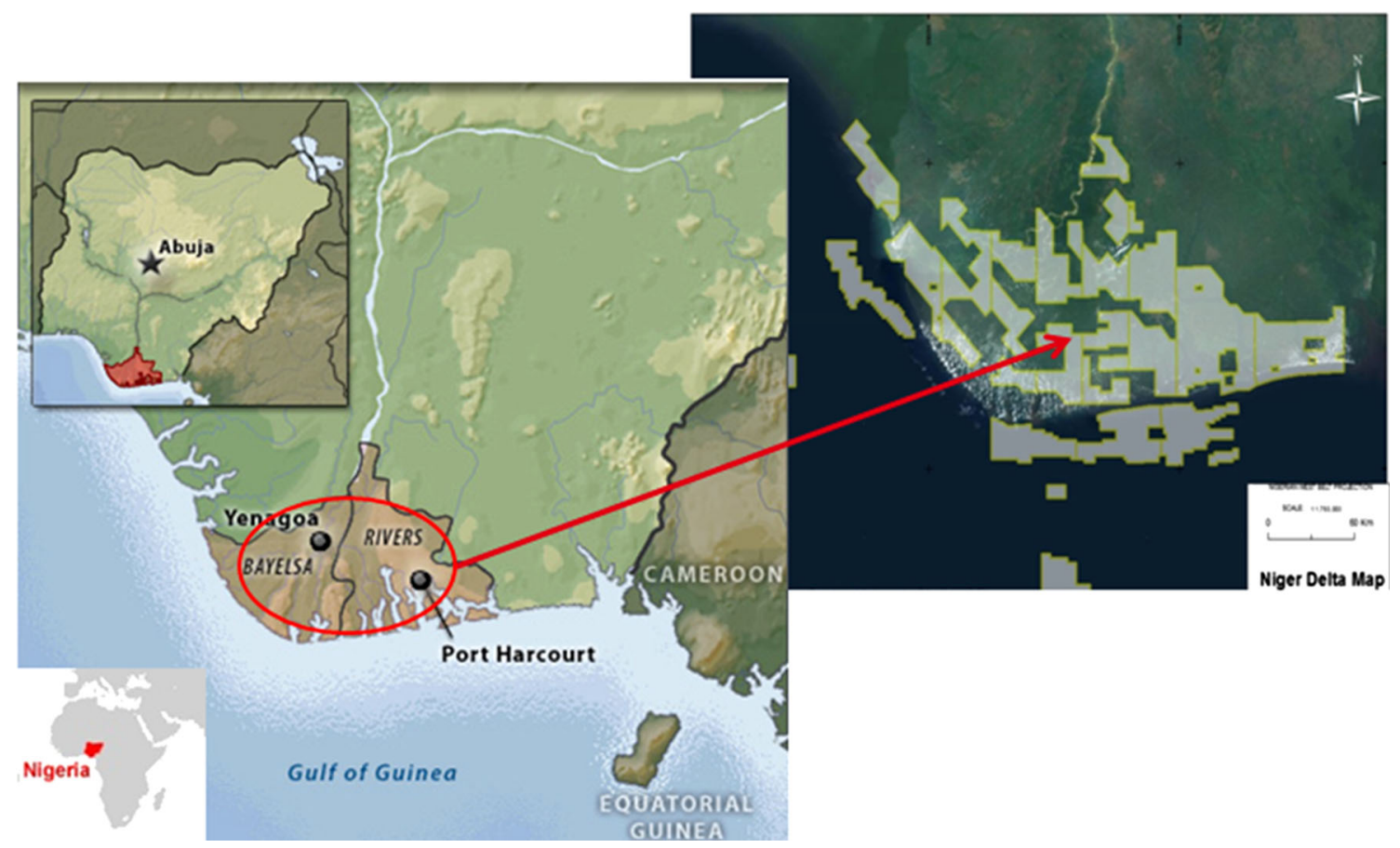

Fig. 1 Maps showing the field of study (the study location is shown by the red arrow)

related these chaotic and distorted reflections beyond $3 \mathrm{~s}$ two-way time most especially, at the footwall of regional faults to the onset of overpressure. Kanu et al. (2014) reviewed the velocity anisotropy considerations using different anisotropy eta values, supported by Zoeppritz's modeling and velocity model updates. The result of their study showed very subtle variations that did not result in improved imaging at the footwall of the regional fault.

However, none of these previous attempts have been directed toward relating shadow effects to multiple reflections. This is because multiples have only until recently been regarded as an offshore phenomenon. These shadow effects at the footwall of boundary faults in onshore seismic data could be as a result of multiple seismic reflections. They occur where geologic bodies having different seismic properties (multiple generators) are in contact, which is a necessary requirement for the creation of adequate acoustic impedance contrast for multiple generations (Weiglein et al. 2011).

Multiples are seismic events that have incurred more than one reflection in its travel path. They constitute the main component of background noise (coherent noise), interfering with data quality and resolution. In relation to the primary reflections to which they are associated, multiples are characterized by low average velocities, low amplitude and frequency, short periods and high normal moveouts (NMO).The short-path (intrabed) multiple as distinct from the long-path multiple is less obvious and the commonest multiple type in onshore seismic data. They are mostly as a result of sedimentations at depth which yield reflection events with almost similar time of arrival as the primary reflection events, such that any time a seismic section becomes indistinct at greater depth, it is hypothesized that the data have become overwhelmed by shortpath multiples and could be investigated (www.Stanford. edu/sep/prof/iei; Retailleau et al. 2002).

In the present study, detailed velocity analysis was carried out in and around the shadow zone to investigate the possible cause of this reflection distortions observed within the shadow zone. This was done using the velocity semblance analysis tool, the objective being to establish the presence of low velocities in the shadow zone which can be associated with multiple reflection events if all other sources of low-velocity phenomenon have been accounted for in the study.

\section{Geology of the study area}

The study area is underlain by three main stratigraphic subdivisions of the tertiary Niger Delta (Fig. 2). These are the Akata Formation, the Agbada Formation and the Benin Formation. The Akata Formation underlies the entire delta and is of marine origin. It is composed of thick shale sequences, turbidite sand, minor amounts of clay and silt and is typically over pressured (Burke 1972). It is estimated that the formation is up to $7000 \mathrm{~m}$ thick (Doust and Omatsola 1990).The overlying Agbada Formation consists 
Fig. 2 Stratigraphic succession map of the Niger Delta

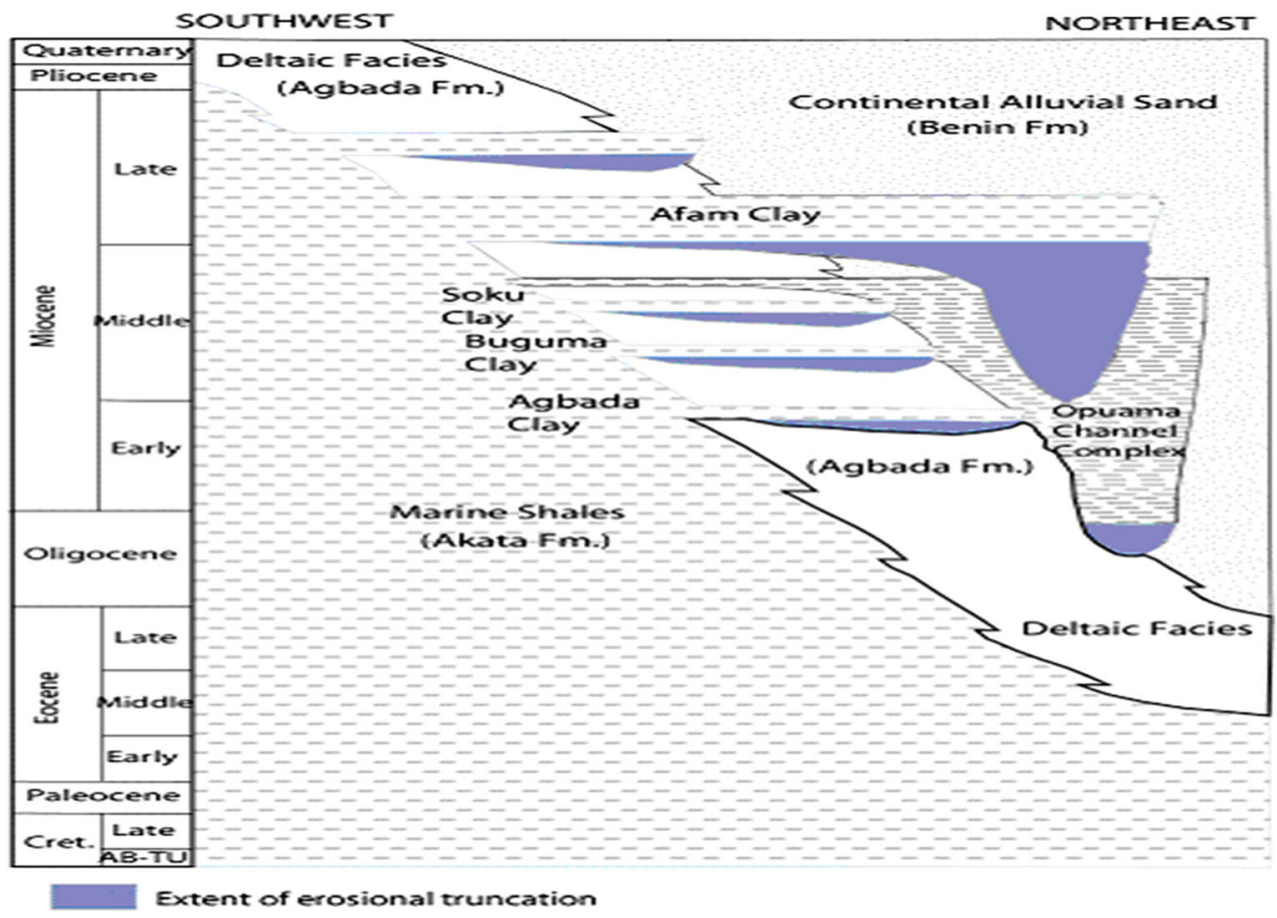

of paralic siliciclastics over $3700 \mathrm{~m}$ thick. This is the actual deltaic portion of the sequence with a lower section comprising of shale and sandstone beds deposited in equal proportions and an upper portion which is mostly sandy, with only minor shale intercalations. The entire Agbada Formation bears petroleum in the Niger Delta (Ejedawe 1981; Evamy et al. 1978; Doust and Omatsola 1990). The third stratigraphic subdivision is the Benin Formation which overlies the Agbada Formation. This consists of alluvial and upper coastal plain sands deposits about $2000 \mathrm{~m}$ thick (Avbovbo 1978). Rollover anticlines in front of growth faults form the main objectives of oil exploration in the Niger Delta, with hydrocarbons being found in sandstone reservoirs of the Agbada Formation (Stauble and Short 1967).

\section{Materials and methods}

3D prestack seismic data used in this research were acquired from an onshore Niger Delta field. It is a long offset $(6 \mathrm{~km})$ and single deep hole acquisition data (Fig. 3). The section shows stronger reflectors bordering the fault shadow zone which is characterized by chaotic and discordant seismic reflection events. VITAL software and SMART SPDC software were used for velocity analysis and model building, respectively, while prestack depth migration (PSDM) was carried out using SPDC PSDM algorithm.

Standard data preparation and enhancement procedures including refraction statics correction, noise attenuation, deconvolution and common midpoint sorting (CMP) were carried out to improve data signal-to-noise ratio. Velocity semblance plots were generated by performing hyperbolic scans on common image point gathers. Velocity picking was carried out based on the principle that the hyperbolic moveout energy for primary reflection events corresponds to the area on the semblance plot with the highest energy clusters. Effective seismic velocities were picked manually on the semblance panel while observing the effect of the pickings on the offset gather panel.

Subsequently, velocity conversions from effective (or rootmean-square) velocity/time to interval velocity/depth were carried out using VITAL software based on Dix equation, which relates depth to interval velocity and two-way time. Based on the result of this analysis, velocity/depth models were built using the resultant interval velocity values. To effectively model the shadow zone, models were generated using velocity functions that were picked from within the zone and used for prestack depth migration (PSDM).

\section{Presentation of results}

Results showed that picking effective velocities away from the shadow zone (Fig. 4a) reasonably flattens the gathers on the offset versus time panel (Fig. 4b). This is an indication that these are primary reflection events. Observe the fairly normal trend of continuous velocity increase with depth on the effective velocity panel (panel a), which is the usual trend in most geologic media.

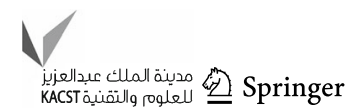




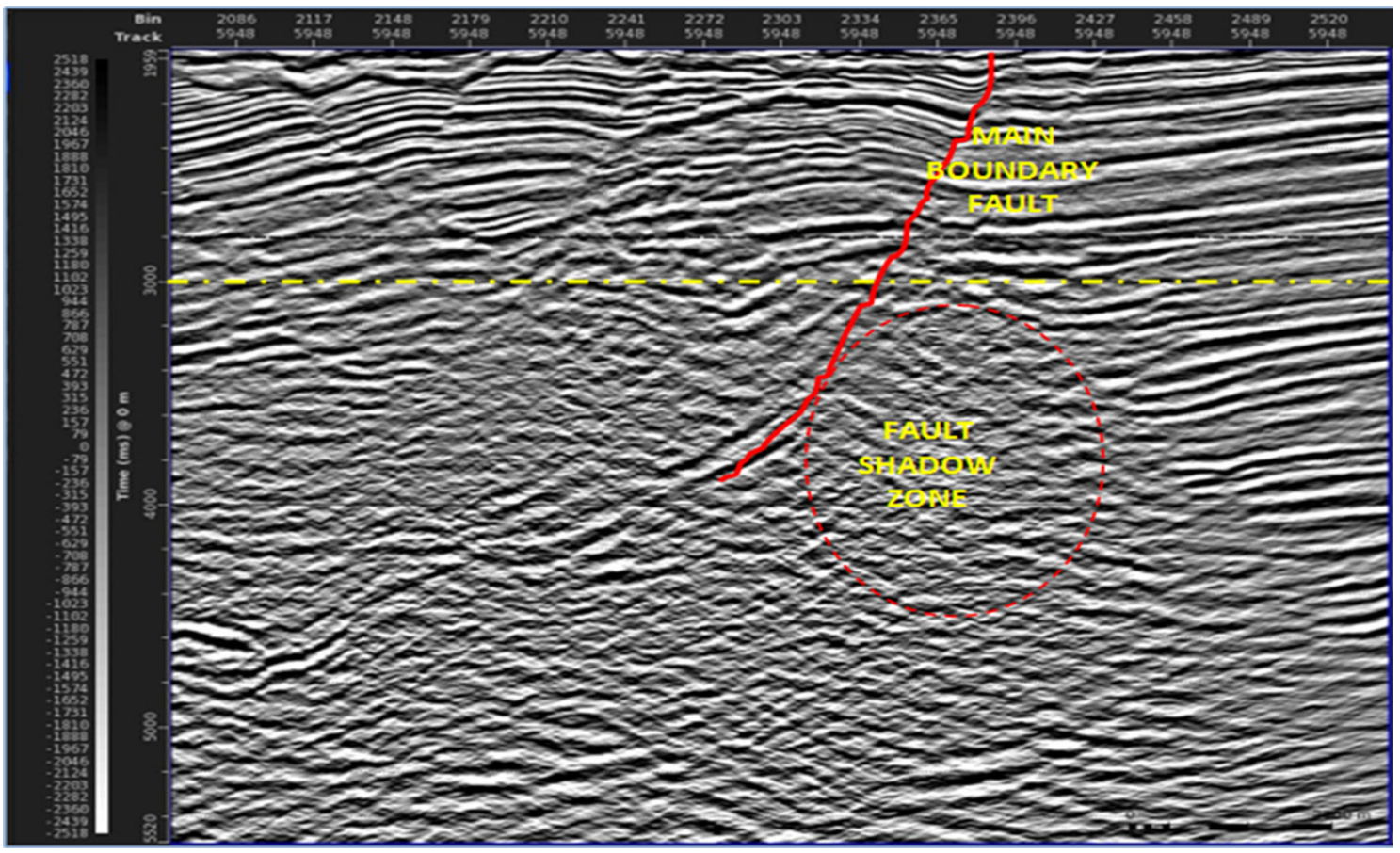

Fig. 3 3D prestack seismic section from the study area

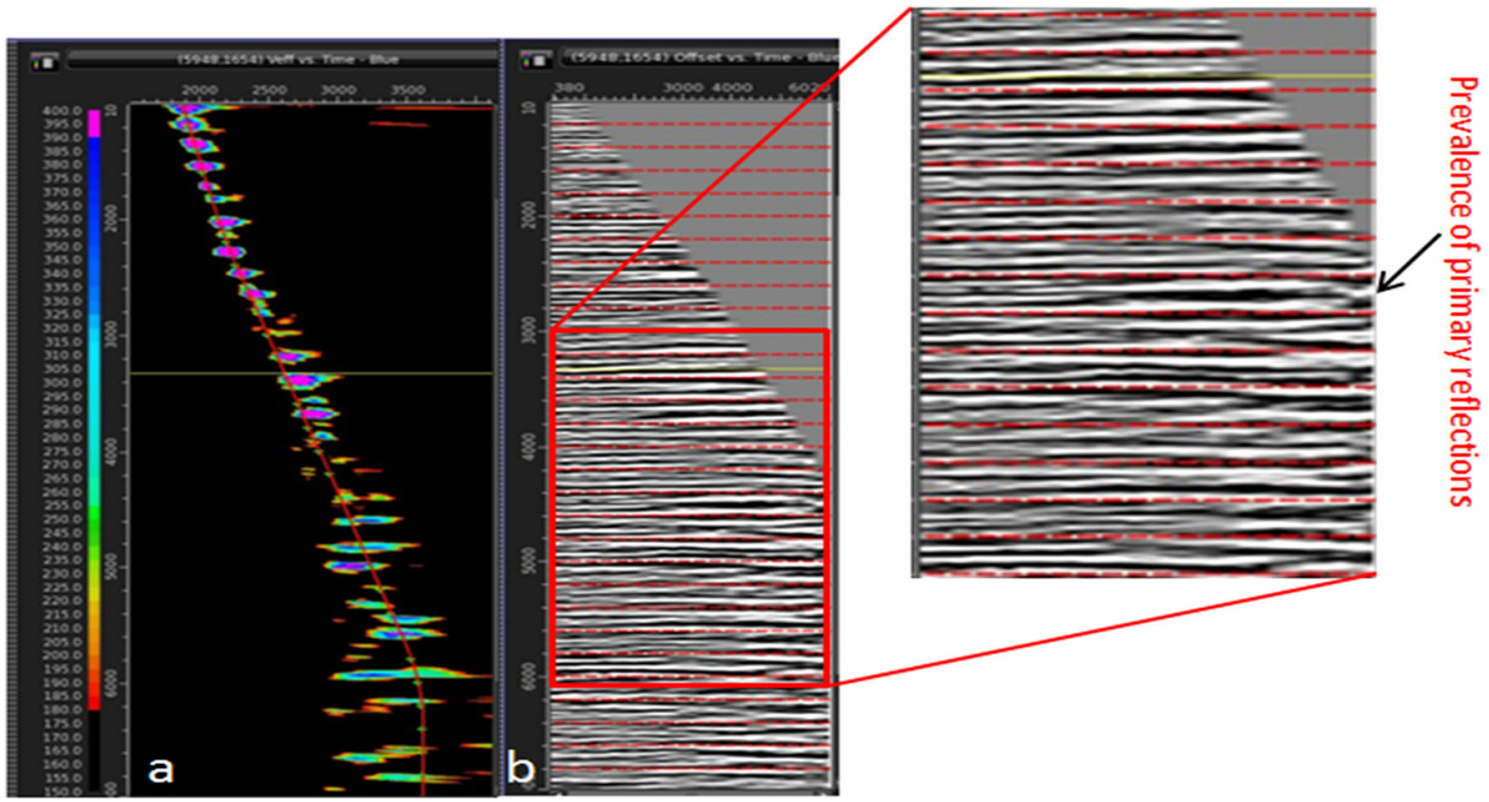

Fig. 4 Picking of effective velocities away from the shadow zone

Picking velocities around and within the shadow zone (Fig. 5a) does not flatten the offset gathers, but positively moves out the events within the gathers (Fig. 5b). This is an indication that these velocities are lower-than-normal primary velocities. These lower-than-normal velocities become predominant beyond $3 \mathrm{~s}(\sim 3800 \mathrm{~m})$ two-way time and remain inconsistently low with depth.
The interval velocity depth model for the primary events away from the shadow zone (Fig. 6) shows a normal and consistent variation of velocity with depth, ranging from about $1500 \mathrm{~m} / \mathrm{s}$ (blue) to about $4500 \mathrm{~m} / \mathrm{s}$ (purple), which is consistent with the local geology of the area.

The velocity depth model within the shadow zone (Fig. 7) shows an increase in interval velocity with depth 


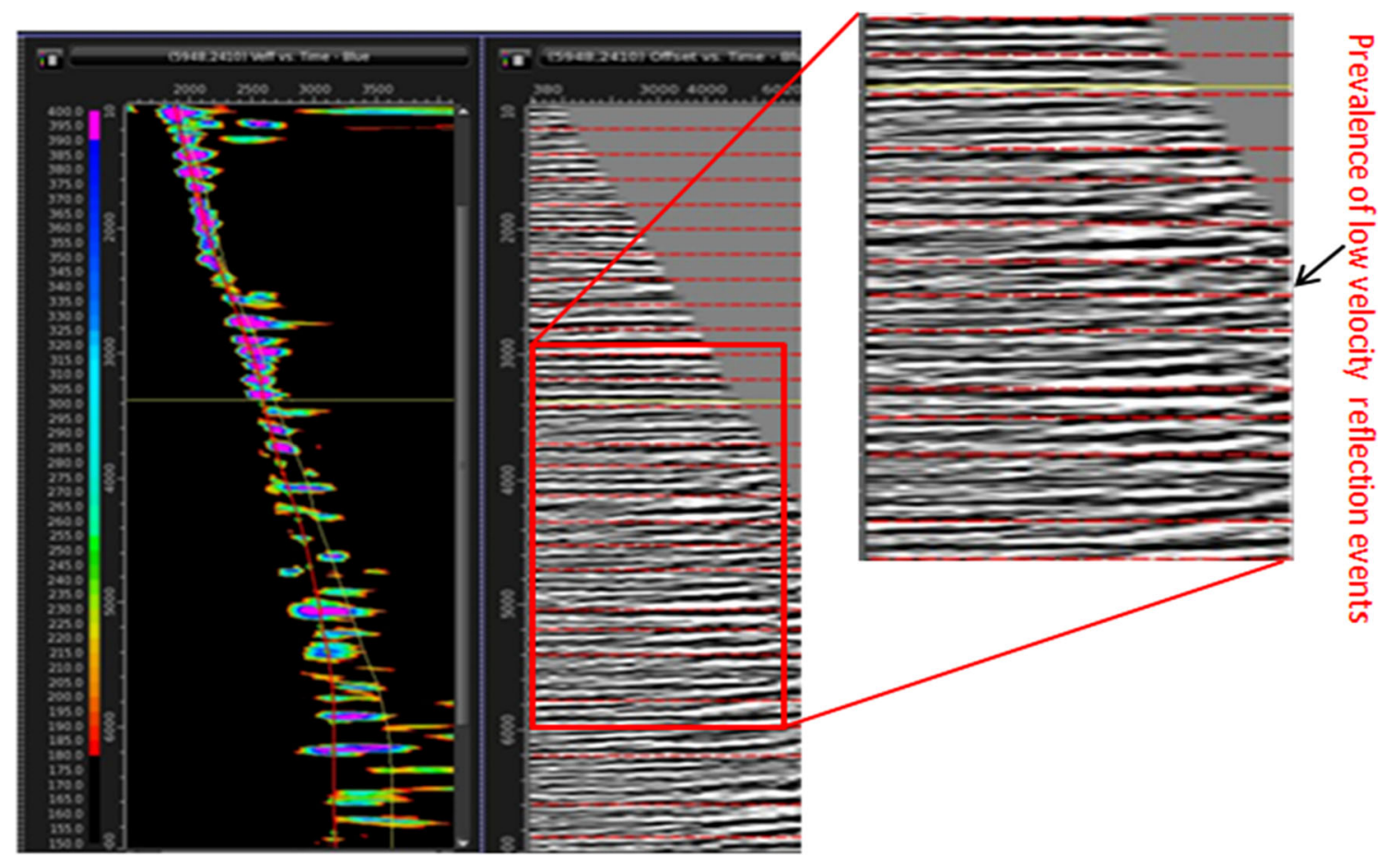

Fig. 5 Picking of effective velocities within the shadow zone

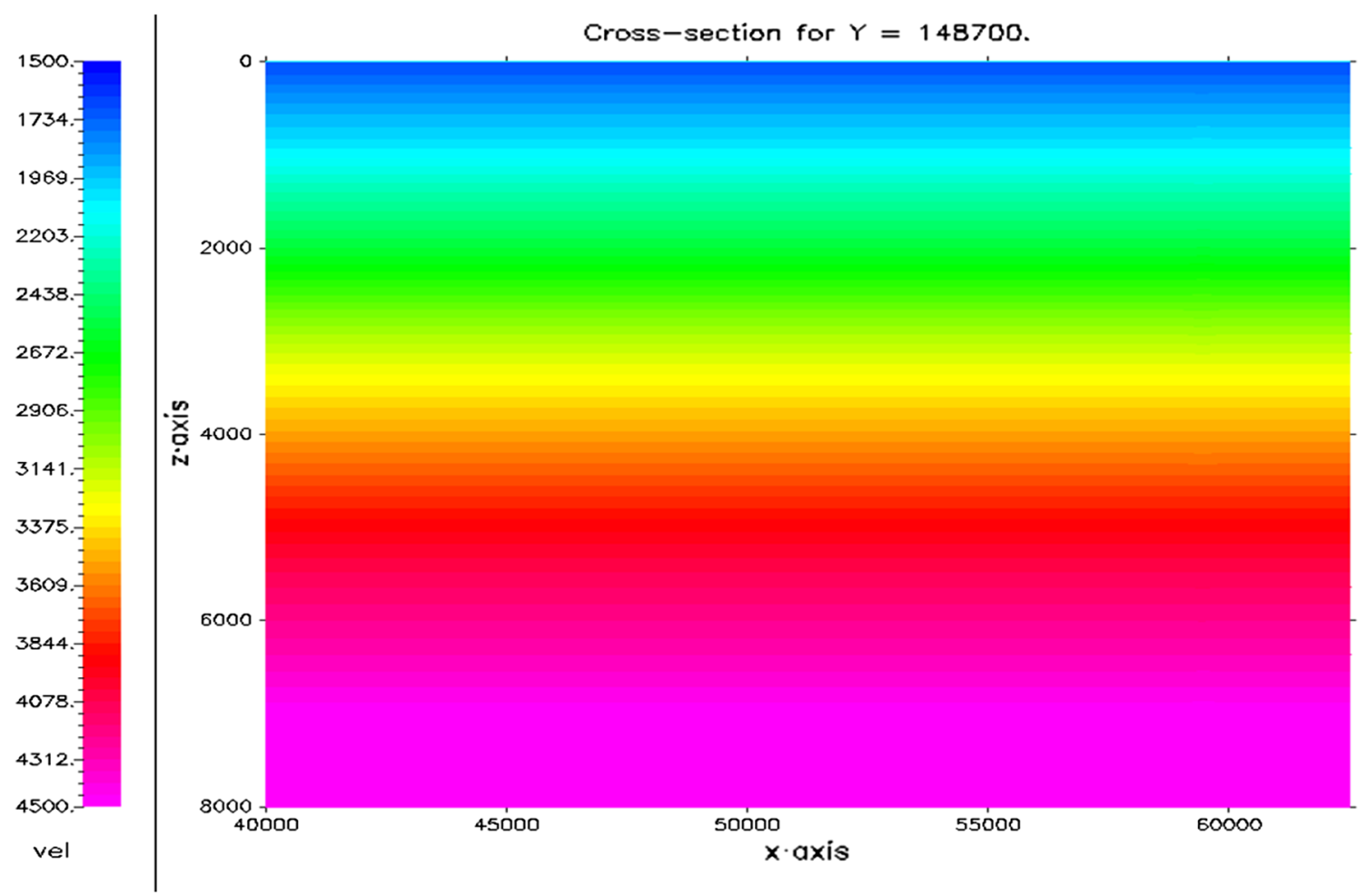

Fig. 6 Velocity/depth model showing the variation of velocity with depth for primary events 


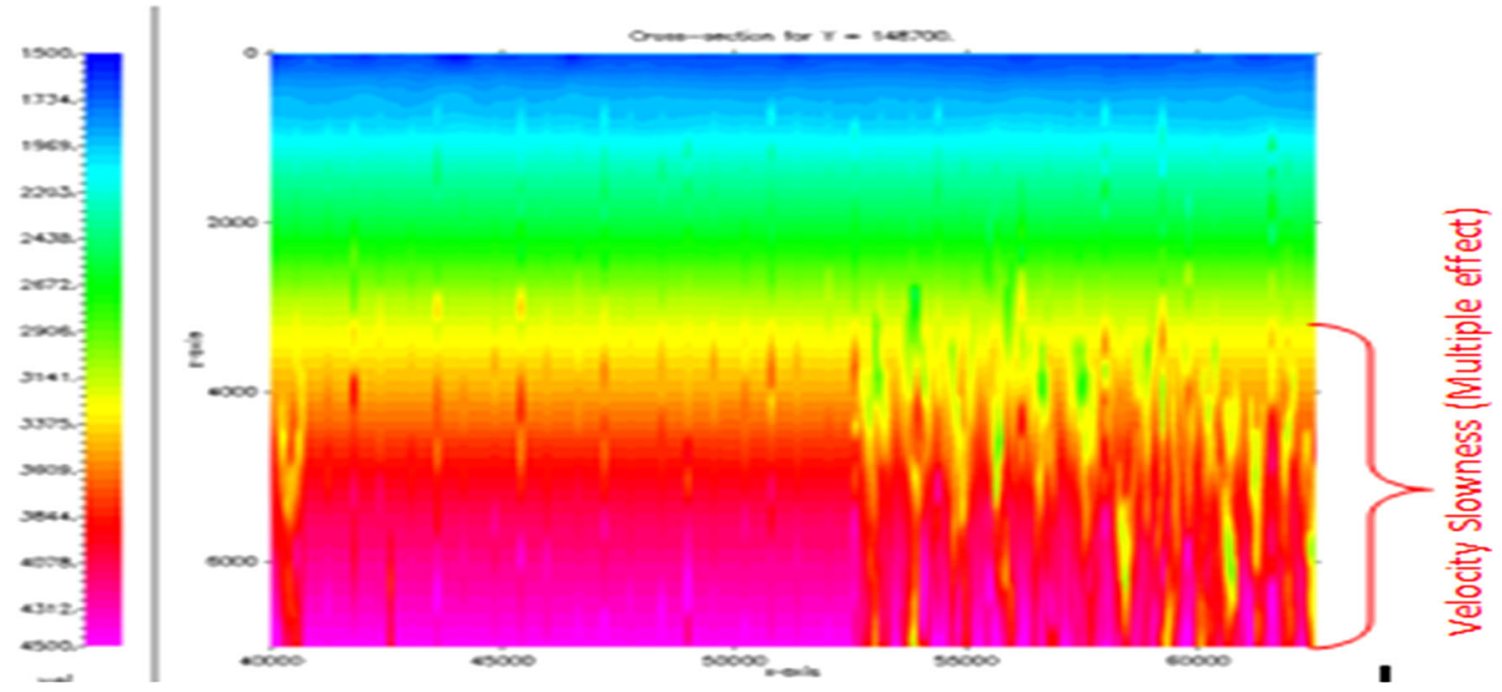

Fig. 7 Velocity/depth model showing the variation of velocity with depth for lower-than-normal velocities

from top to about $3800 \mathrm{~m}$. Beyond this depth and around the shadow zone, low-velocity incursions were observed. These low-velocity incursions are associated with lowerthan-normal velocity events in the shadow zone.

These velocity variations for the two models can be demonstrated in a depth/interval velocity plots away and within the shadow zone (Fig. 8).We observe that the depth/ interval velocity plot for the primary events away from the shadow zone (Fig. 8a) varies normally with depth, in agreement with the interval velocity model, while the depth/interval velocity plot (Fig. 8b) within the shadow zone, however, shows an increase in interval velocity with depth from top to about $3800 \mathrm{~m}$, beyond which we observe the onset of lower-than-normal velocities (red ellipse).

The PSDM section before the detailed velocity analysis was carried out in this study (Fig. 9) illustrates the chaotic and discordant seismic reflection events within the fault shadow zone (black circle). Also, observe the stronger reflectors bordering the fault shadow zone.

The result of migrating with primary velocities (Fig. 10) shows better continuity of reflection events away than within the shadow zone. However, reflection events within the shadow zone appear enhanced than the initial PSDM, but the shadow effect is still evident. This is because the primary velocities could not properly account for the lower-than-normal velocity events within the shadow zone.

Migrating with lower-than-normal velocities shows that the distorted reflection events within the shadow zone are no longer obvious, but coherent and continues within the shadow zone (Fig. 11). This suggests that these lower-thannormal velocity events (the green arrows) have been well

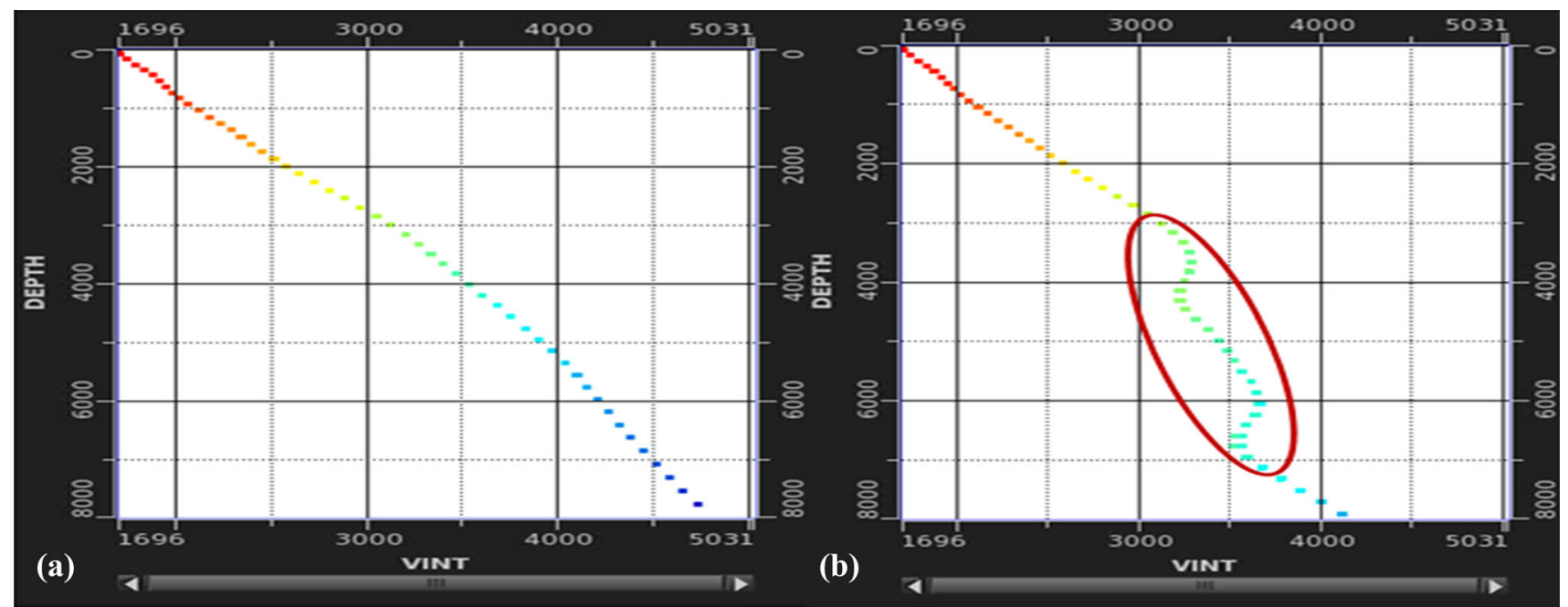

Fig. 8 Velocity (interval velocity)/depth variation for primaries (a) and lower-than-normal velocities (b) 


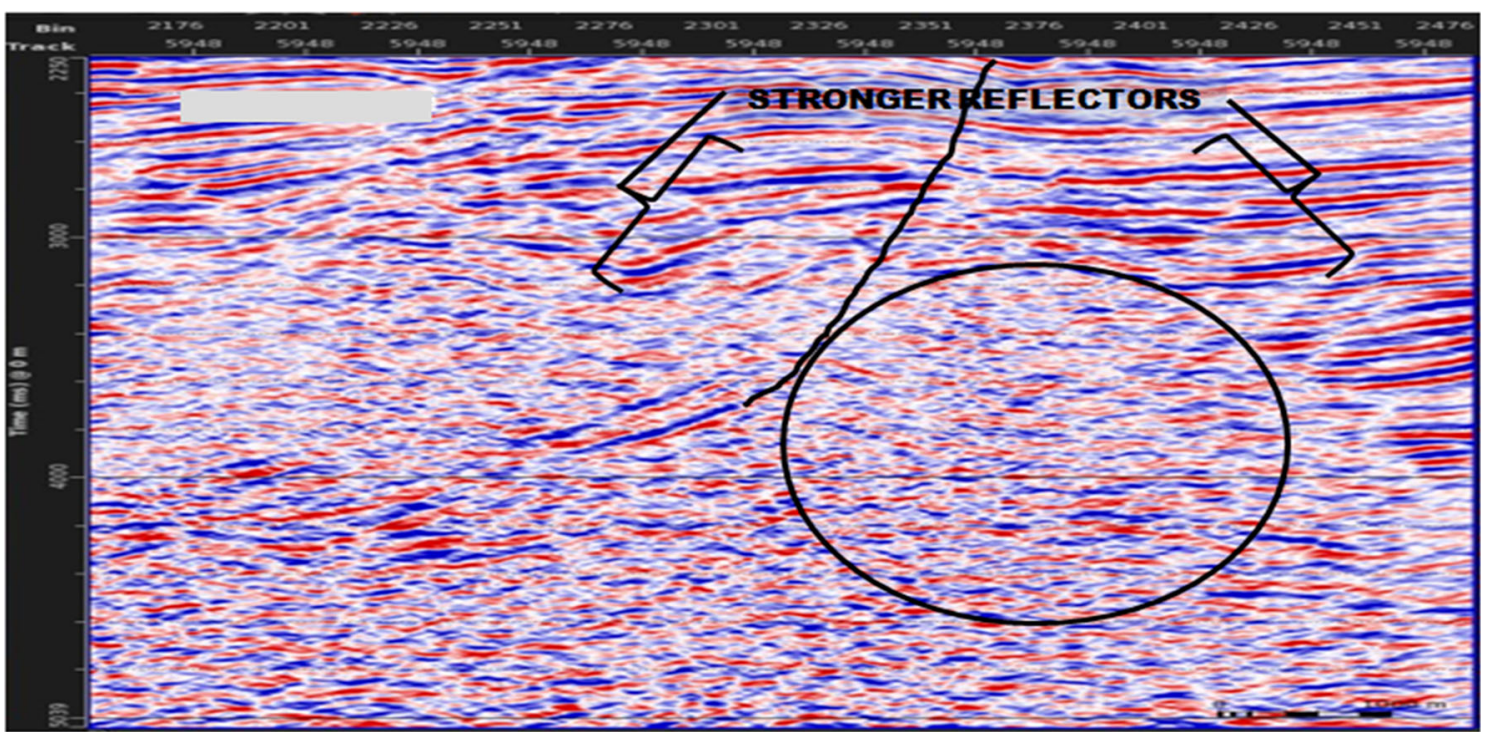

Fig. 9 PSDM section before the detailed velocity analysis. Observe the chaotic distortions in the fault shadow zone and the stronger reflectors bordering the zone

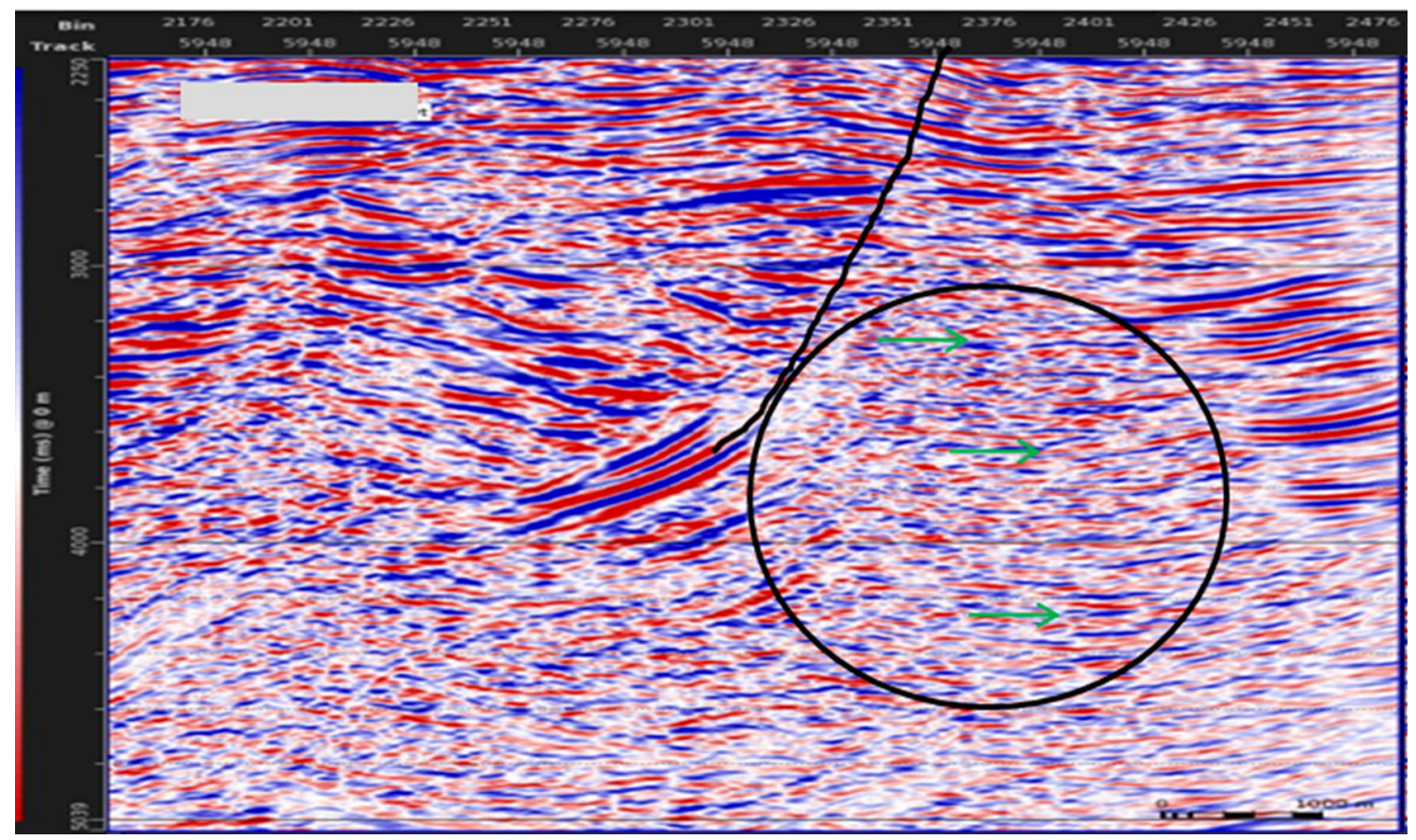

Fig. 10 PSDM section with the primary velocities

accounted for in the shadow zone by migrating with the right velocity.

These lower-than-normal velocity events in the absence of overpressure and anisotropy which has been accounted for by previous researchers in the study area are interpreted as short-path multiple reflection events.

\section{Discussion of results}

Multiples have been analyzed as a prelude to fault shadow phenomenon using 3D prestack seismic data from onshore Niger Delta. This was done through detailed velocity analysis of reflection events away and within the fault shadow zone. 


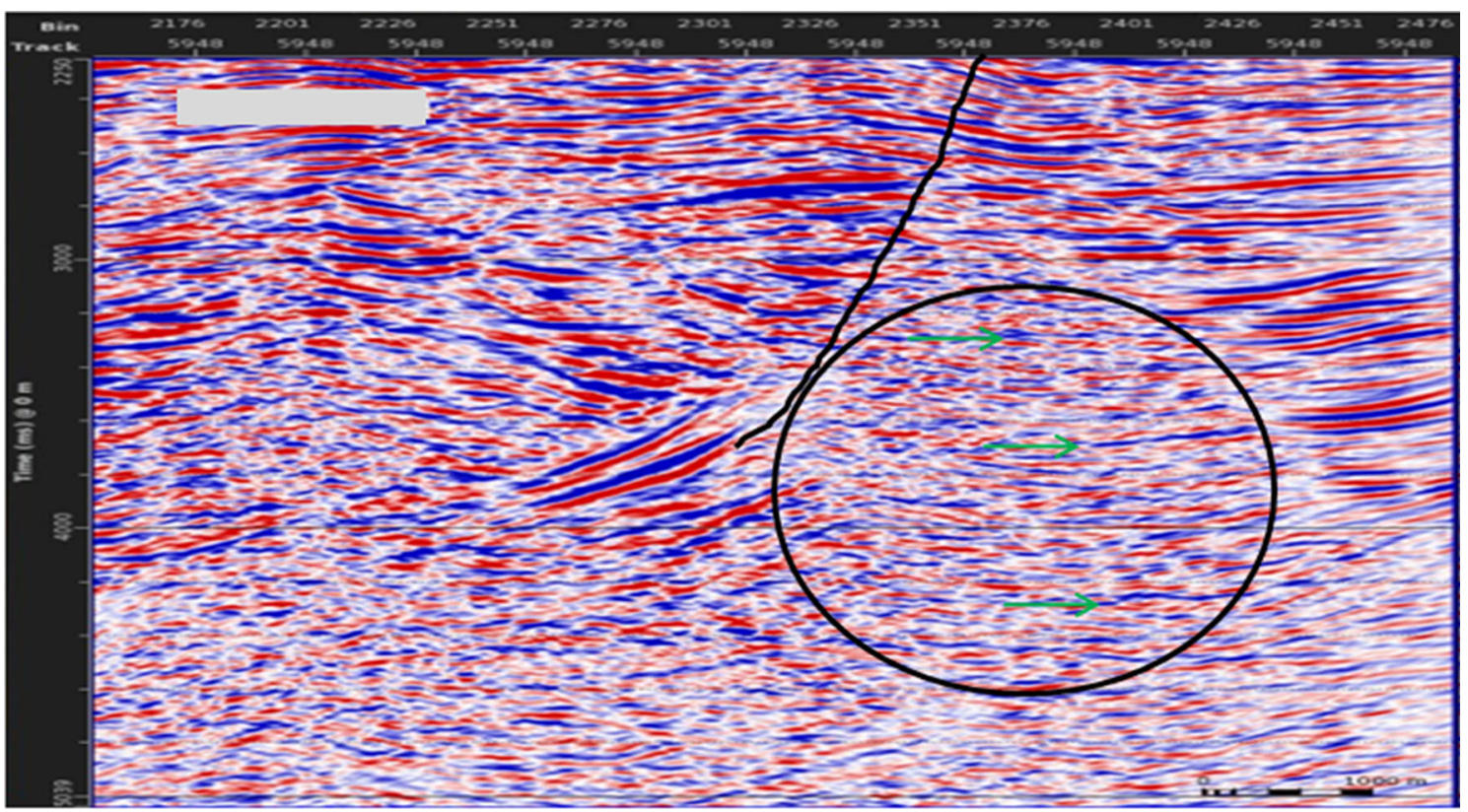

Fig. 11 PSDM section with the lower-than-normal velocities

Results show that picking velocities away from the shadow zone flattened out reflection events in the offset gathers, indicating that they are predominantly primaries. However, picking velocities within the shadow zone did not flatten the gathers, but rather gave them a negative moveout. These lower-than-normal velocities overcorrected the gathers, indicating a non-primary reflection event in the shadow zone. These effective velocities were converted to interval velocities, and subsequently interval velocity depth models were generated for the two velocity scenarios and used as inputs in PSDM migration.

Migrating with the primary velocities accounted for the primary reflections away from the shadow zone. Within the shadow zone, the reflection events appear a bit enhanced and aligned than the initial PSDM data. However, the shadow effect is still evident, with no discernible reflection events and structures. This is because the primary velocities could not properly account for the lower-than-normal velocity events within the shadow zone. The result of migration with the lower-than-normal velocities shows that reflections within the shadow zone are coherent, continuous and better aligned. This is an indication that these lower-than-normal velocity events have been well accounted for in the shadow zone by migrating with the right velocity.

These tie perfectly well with the area on seismic corresponding to the footwall of the main boundary fault. As observed in this study, locations away from the footwall of the fault, the velocities are predominantly primary, while behind the footwall of the fault (corresponding to the fault shadow zone), lower-than-normal velocities predominant. This is considered as the primary cause of the reflection distortions and misalignment of events observed in the fault shadow zone.

These lower-than-normal velocity events in the absence of overpressure and anisotropy which has been accounted for by previous researchers in the study area (Dutta 2002; Aikulola et al. 2010; Oni et al. 2011; Kanu et al. 2014) are regarded as short-path multiple reflection events. The presence of strong subsurface reflectors and contacts between geologic bodies of different seismic properties at the footwall of the main boundary fault (beyond $3 \mathrm{~s}$ twoway time) is suggested as the probable causes of this multiple effect.

The result of the present study has shown that multiples which have until recently been regarded as an offshore phenomenon have been detected in onshore seismic data. Consequently, these reflection distortions observed beyond $3 \mathrm{~s}$, especially within the shadow zone, are attributed to multiple reflected seismic events.

\section{Conclusions}

Detailed velocity analysis and 3D PSDM of a 3D seismic data in a Niger Delta field revealed the presence of lowerthan-normal velocities in the shadow zone considered as the primary cause of the reflection distortions and misalignment of events observed in the zone, which is suggested to be due to multiple reflection events. This occurs beyond $3 \mathrm{~s}$ two-way time $(3800 \mathrm{~m})$, especially at locations corresponding to the footwall of main boundary faults on seismic. 
This assertion is made based on the fact that all sources of low-velocity events at this depth such as overpressure and anisotropy have been accounted for by previous researchers in the study area and as such, multiple effects are the plausible candidate for the observed reflection distortions observed in the shadow zone.

Acknowledgements We acknowledge the support of SPDC Port Harcourt in providing Mr. George-Best with an Internship opportunity that paved way for this study and for being the source of the dataset, the computing facilities used in this research and for granting the permission to publish this work.

Open Access This article is distributed under the terms of the Creative Commons Attribution 4.0 International License (http:// creativecommons.org/licenses/by/4.0/), which permits unrestricted use, distribution, and reproduction in any medium, provided you give appropriate credit to the original author(s) and the source, provide a link to the Creative Commons license, and indicate if changes were made.

\section{References}

Aikulola UO, Olotu SO, Yamusa I (2010) Investigating fault shadows in the Niger delta. TLE 29(1):16-22

Avbovbo AA (1978) Tertiary lithostratigraphy of Niger Delta. Am Assoc Pet Geol Bull 62:295-300

Burke K (1972) Longshore drift, submarine canyons, and submarine fans in development of Niger Delta. Am Assoc Pet Geol 56:1975-1983

Doust H, Omatsola E (1990) Niger Delta. In: Edwards JD, Santogrossi PA (eds) Divergent/passive Margin Basins, AAPG
Memoir 48. American Association of Petroleum Geologists, Tulsa, pp 239-248

Dutta NC (2002) Geopressure prediction using seismic data: current status and the road ahead. Y2K Review Article. Geophysics 67(6):2012-2041

Ejedawe JE (1981) Patterns of incidence of oil reserves in Niger Delta Basin. Am Assoc Pet Geol 65:1574-1585

Evamy BD, Herebourne J, Kameling P, Knap WA, Molley FA, Rowlands PH (1978) Hydrocarbon habitat of Tertiary Niger Delta. Am Assoc Pet Geol Bull 62:1-39

Fagin S (1996) The fault shadow problem: its nature and elimination. Lead Edge 15(9):1005-1013

Haack RC, Sundararaman P, Diedjomahor JO, Xiao H, Gant NJ, May ED, Kelsch K (2000) Niger Delta petroleum systems, Nigeria. In: Mello MR, Katz BJ (eds) Petroleum systems of South Atlantic margins, vol 73. Am. Assoc. Petrol. Geol. Memoir, pp 213-231

Kanu M, Madiba G, Emakpor J, Olotu S, Mbah R, Obilaja S (2014) Demystifying the Fault Shadow Challenge in Onshore Nigeria. (C) Shell Petroleum Development Company, Port Harcourt

Kulke H (1995) Nigeria. In: Kulke H (ed) Regional petroleum geology of the world part 1l, Gebruder Bortraeger, Berlin, Africa, America, Australia and Antarctica, pp 143-172

Oni AA, Madiba G, Bertram MO (2011) Anisotropic Imaging of Okubotin 3D, Onshore Niger Delta, Article, January, 2011. www.researchgate.net

Retailleau MG et al (2002) 74th EAGE Conference and Exhibition incorporating SPE EUROPEC 2012. Copenhagen, Denmark

Short KC, Stauble AJ (1967) Outline of geology of Niger Delta. AAPG Bull 51:761-779

Weiglein AB, Hsu SY, Terenghi P, Li X, Stolt RH (2011) Multiple attenuation: recent advances and the road ahead. Lead Edge 30(8):864-875

www.Stanford.edu/sep/prof/iei

www.intechopen.com 